Brock Education, Vol 18, 2008

\title{
Aboriginal epistemologies and new teacher induction: The context of a bi-epistemic research endeavour
}

\author{
Lorenzo Cherubini: Brock University, Canada \\ Julian Kitchen: Brock University, Canada \\ John Hodson: Brock University, Canada
}

\begin{abstract}
Teacher preparation and induction have been the subject of much scholarly investigation in the mainstream, however, relatively little research has focused on Aboriginal epistemologies and new teacher experiences. From a bi-epistemic perspective, this research project attends precisely to this void in the scholarship. The project represents an innovative partnership between an Aboriginal research centre, an esteemed elder, university scholars, graduate students, and Aboriginal educators in Ontario. Furthermore, it calls attention to the successes of new Aboriginal teachers and the dedication they exemplify to advance Aboriginal epistemologies and student learning from culturallysensitive perspectives.
\end{abstract}

\section{Introduction}

There is an extensive body of research on teacher induction. The mainstream literature accounts for the perils of insufficiently supporting new teachers in managing the wide array of responsibilities of their professional roles (Alliance of Excellence in Education, 2004; Danielson, 2002). It has been well-documented that effective induction programs assist in retaining those already in the profession (Darling-Hammond, 2003; Ingersoll \& Smith, 2003). Induction programs that are responsive to teachers' backgrounds and consider their understandings of what it means to teach are particularly successful (Olebe, 2005; Smith \& Ingersoll, 2004; Williams, 2003). Bartell (2005) stated that induction programs are well served to address beginning teachers' "instructional, professional, cultural, and political needs" (p. 116) and are best delivered in the context of reflective practice (see as well Portner, 2002; Tushnet, Briggs, Elliot, Esch, Haviland, \& Humphry, 2002).

While it is true that teacher preparation, induction, and new teacher perceptions have been the subject of much scholarly investigation in the mainstream, relatively little research has focused on Aboriginal epistemologies and new teacher experiences. Aboriginal knowledge and epistemologies, considered to be dynamic and fluid entities, are taught and learned predominantly by active participation and relationship in Aboriginal communities (Brayboy, 2005; Cajete, 1999). The preservation of the historical, linguistic, and spiritual traditions unique to these cultures necessitates the engagement of Aboriginal teachers and researchers who are intimately familiar with them (Battiste, 2002; Country Roads, 2000). The literature about new Aboriginal teachers' experiences in the classroom, the challenges they encounter in the first years of teaching, and the impact of their teacher education programs on their practice is, however, virtually silent (Author). From a bi-epistemic perspective, this research project attends precisely to this void in the scholarship. Of further import, it calls attention to the successes of new 
Aboriginal teachers and the dedication they exemplify to advance Aboriginal epistemologies and student learning from culturally-sensitive perspectives.

\section{Conceptual Framework}

\section{Aboriginal epistemologies}

Indigenous epistemologies have "fared spectacularly badly" in university settings and as a consequence "resistance and refusal have been felt within school systems that take their cues and key features of their curricula from their educational 'betters' within mainstream knowledge hierarchies" (Battiste, Bell, Findlay, Findlay, \& Henderson, 2005). Aboriginal knowledge orientations are not necessarily evident in mainstream research and scholarship that are more reflective of Eurocentric paradigms (Iseke-Barnes, 2002; see also, Cajete, 1994; Castellano, 1997; Die et al., 2000; Tedla, 1992). In fact, Aboriginal scholars advocate for a distinct intellectual niche to distinguish themselves from colonial educational paradigms (Battiste, 2002; Hill, 2000; Kawagley, 1995; Womack, 1999). It must be understood that Aboriginal knowledge is considered specific to people and place and is transmitted cross-generationally:

In forcing assimilation and acculturation to Eurocentric knowledge, modern governments and educational systems have displaced Indigenous knowledge. It is clear, however, that the exclusive use of Eurocentric knowledge in education has failed First Nations children. (Battiste, 2002, p.9; see also Ascher, 1991; Schissel \& Wotherspoon, 2003)

The Ontario Aboriginal Policy Framework document (2007) recommends that faculties of education in Ontario prepare more Aboriginal teachers who are culturallyknowledgeable (Aboriginal Education Office, 2007). Aboriginal epistemologies focus on pedagogy that teaches through culture and fosters student awareness about the intricate connections they share with others and the natural environment (Barnhardt, 2005). Aboriginal educators have an instrumental role in preserving Aboriginal languages and cultures to further the self-determination of Aboriginal students.

\section{The Ontario Context}

The legislation in Ontario requires that all new teachers successfully complete the New Teacher Induction Program (NTIP). School boards are responsible for providing various systemic and mentoring support networks for new teachers. Aboriginal communities, however, are faced with the challenge of coping with the limited number of new Aboriginal teachers who are qualified to address the unique cultural, linguistic, and learning preferences that are crucial to the academic success of Aboriginal children (Sawyer, 1991). At present, many Aboriginal elementary teachers in Ontario are not officially certified according to the Ontario College of Teachers, the self-regulatory body of the province's teachers. Consider too the unprecedented increase in the numbers of Aboriginal children who will contribute to a shortage of Aboriginal elementary teachers in Ontario, especially in remote communities such as those that are part of the Nishnawbe-Aski First Nations in northwestern Ontario.

For Aboriginal peoples the learning of language implies a tacit relationship to traditional knowledge and communication systems that sustain Aboriginal culture and tradition (Battiste, 2008). Currently Ontario has the lowest ratio of Aboriginal population and teacher representation in Canada (3.6\% of Aboriginal peoples between $1-14$ years are represented by $0.5 \%$ of Aboriginal teachers' share of employment (Our Children: 
Keepers of the Knowledge, 2002). This often translates into Aboriginal teachers having to function in what they perceive to be racist and discriminatory school cultures (Archibald et al., 2002; McNinch, 1994). Further, First Nations communities have on more than one occasion identified the impediments in hiring and retaining Aboriginal teachers to transfer traditional language and knowledge to Aboriginal students (Morgan, 2002; Intellectual Property for Aboriginal People, 1999).

\section{Context of Study}

The project employed the Wildfire Gathering (WG) (Author) and included a sample of new Aboriginal teachers across Ontario that included Anishinabe, Hotinonshó:ni, Nishnawbe-Aski, and Métis teachers The WRM provides a communal and sacred research environment that respects the traditional and cultural beliefs of Aboriginal people (Author). This is consistent with Cajete's (2008) observation that "Indigenous educational research is best performed when an Indigenous view and purpose are represented in the conceptualization, development, and implementation of research" (Cajete, 2008, p. 204).

The project represents an innovative partnership between an Aboriginal research centre, an esteemed elder, university scholars, graduate students, and Aboriginal educators in Ontario. The bi-epistemic research team acknowledged and respected both Aboriginal and mainstream knowledge traditions in order to garner more profound understandings of Aboriginal epistemologies and new teacher experiences.

\section{Participants}

The sample of the study included six new teachers from the four dominant Aboriginal groups in Ontario. Two participants were male, one was Mohawk and the other was an Anishinabe-Odawa man. Both males have one year of experience working in publicly funded schools. Of the female participants, two were from the Anishinabek Nation; the other two female participants were from the Métis and Mohawk Nations. All participants were between thirty and forty-five years of age. Three of the females teach in On-Reserve schools and the other in a publicly funded school. Two of the female teachers have five years teaching practice while the other two are professionals with one or two years. Participants attended the Wildfire Gathering over the course of 3-days in December 2007, at a location that had symbolic and spiritual significance.

\section{Data analysis}

The research team borrowed tenants of grounded theory to provide "a procedure for developing categories of information, interconnecting the categories, building a "story" that connects the categories, and ending with a discursive set of theoretical propositions"(Strauss \& Corbin, 1990, as cited in Creswell, 1998, p. 150). The individual responses were considered "textual wholes, not as reflecting some reality outside the spoken words," and thus themes were coded to identify emerging patterns in the data (Hilden \& Honkasalo, 2006, p. 44). Codes and categories were juxtaposed and discussed. The relationships among these themes were inductively derived in the process of constant comparison (Author; Glaser \& Strauss, 1967).

\section{Reflections}


Engaging in research from a bi-epistemic perspective presents various challenges (Author). Implied in such an endeavour is a mutual respect and recognition for each other's epistemology and understandings of outcomes grounded in the data and subsequently contextualized from culturally-rich perspectives. From both paradigms it was concluded that the WG established a professional community of new Aboriginal teachers that was conducive to candid dialogue (Hargreaves \& Fink, 2003). This is reminiscent of Smith and Ingersoll (2004) who identified new teachers' participation in collegial networks of teachers as an important component of teacher induction (see also, Hirsch, 2006). It also resulted in a synergy between participants that lent emotional support for their experiences as new teachers (see, for example, Wilkins \& Clift, 2007, p. $31)$.

Teacher preparation (Avila de Lima, 2003; Hobson, Malderez, Tracey, \& Kerr, 2005), induction (Guarino, Santibanez, \& Daley, 2006; Rippon \& Martin, 2006), and new teacher beliefs in mainstream education (Luft, 2005; Younger, Brindley, Peddar, \& Hagger, 2004) are topics that have enjoyed widespread publication. The same cannot be said for Aboriginal attitudes and perceptions of their professional education preparation and induction. Aboriginal teachers are motivated to enhance student success, yet the literature is seemingly unresponsive to new Aboriginal teachers' experiences, concerns, and successes (Archibald et al., 2002; Goldsmith, 1993).

\section{Participants' Voices}

The bi-epistemic research endeavour under discussion is in response to this neglect. Our research honours the voices of the participants - the new Aboriginal teachers themselves. In many instances the participants echoed the literature in their candid expressions of struggle and sacrifice during their induction into teaching. New teacher participants shared their stories of isolation. One participant shared their initial experiences in a mainstream school by stating, "the only one that would greet me in the morning and say hi was the custodian....I would walk into the staff room [and] everybody would go quiet." All participants related to some experience of being assigned classrooms "at the other end of the [school] building and feeling very isolated." One new teacher described being treated, "like you're not a real teacher." This prompted another to lament, "there is no training on how to work with [mainstream] colleagues."

Participants also discussed the lack of support during their first years of teaching. One new teacher stated, "I didn't have any paperwork [curriculum resources] - nothing. Whatever materials they had at the school were not coinciding with the expectations of the provincial guidelines." This lack of curriculum-related resources, combined with Aboriginal language classes consisting of over thirty students was quite understandably considered to be "overwhelming" to the new teacher participants. These challenges only compounded new teachers' anxiety when dealing with students with special needs. Participants shared their frustrations with having educational assistants assigned to their students who "have never been in the classroom" because of a lack of federal-funding (from Indian and Northern Affairs Canada). They commented on the futility of having one educational assistant tending to the multiple and varied needs of two classrooms of students. As one individual described, "there's just way too many students who are special needs." Consider as well participants' perceptions that the curriculum itself is disconnected from students' experience. New teachers were forthright in suggesting that "there's something wrong with the curriculum if these students are not retaining any of 
that language their learning." As a result participants empathized with one another's claims that, as one new teacher concluded, "One of the biggest challenges I face in my job is how to get kids engaged who don't see any reason whatsoever for education," and who, as another participant noted, "are not living the language." These notions support the continuing decline in key indicators of Aboriginal cultural health that includes the disappearance of 50 of 53 languages (Fishman, 2001; Lafrance, 2000). The collective resolve of these new Aboriginal teachers was effectively summarized by one participant who stressed the importance of "building our own curriculum. Waiting for somebody else to come along or waiting for somebody else to make it may never happen."

Despite their cultural, historic and geographic diversity, participants perceive learning as a holistic and lifelong process for the betterment of their community (as discussed in Canadian Council on Learning, 2007). The participants' resolve in the face of these challenges brings to light the resurgence of Aboriginal self-determination whereby new pedagogies and methodologies are being developed to decolonize their students and schools (Grande, 2004; Lomawaima \& McCarty, 2006; Smith, 1999).

Further, and of particular importance to this research, is the attention it brings to what has not been documented in the mainstream literature; namely, the successes of new Aboriginal teachers and their commitment to sustain Aboriginal epistemologies and student learning from culturally-sensitive paradigms. The new teacher participants were well-aware of the impact schools have in terms of reproducing asymmetrical power relations among cultures (Giroux, 1992; Freire, 1985). Yet, they expressed a commitment to educate mainstream teachers about what one individual described as their "very rich culture and background [that] has nothing to do with money." Participants commented on their intent to "educate the non-Native educators to see that our culture is equal and valuable... and not try to equate or compare our culture and values with their white values." New Aboriginal teachers framed their commitment around student welfare and success. Common references throughout the 3-day Wildfire Gathering sessions included participants' sensitivity to students' "self-esteem" as being integral to their sense of belonging in schools. The new teacher participants aligned their own "passion for the language" to serving what another individual described as, "that role model and that connection that the students had to make [to] feel more at home at school."

On many occasions participants reiterated the interconnections between language, culture and epistemologies and how these have contemporary implications on their practice and on their personal lives. As this individual shared, "I've been taking back my language...doing everything I can to educate our youth...changing the cycle is tough." Despite the difficulties, isolation, and lack of support during their induction participants' voices left a clear impression of an unwavering belief that "those little brown faces... are going somewhere. I believe that part of my goal is to give them that hope for something better in their future." Typical of other comments, another individual stated, "I feel that somebody has got to be there believing in the kids, believing in their ability to be there [school], to be proud, to be hard-working... we owe it to our elders who have fought so hard." 


\section{Summary}

There has been an inequitable focus on Aboriginal education and Aboriginal teachers' perspectives and experiences (Moyle, 2005; Orr \& Friesen, 1999) despite the pressing need to prepare Aboriginal educators to teach Aboriginal students and in doing so to preserve their passing cultural and linguistic traditions (Neegan, 2005). Aboriginal education and epistemology entails a social capital that includes sustaining a sense of community built on relationships and a profound respect for nature and the land (Moody \& Cordua-vonSpecht, 2005). Our research into their experiences within their communities aims to contribute to the understanding of the community they serve and, particularly, how Aboriginal teachers can best be supported as they work to renew their languages and cultures through education.

\section{Acknowledgement}

This research is supported by a 2-year Social Science and Humanities Research Council (SSHRC) grant from the Canadian federal government. 


\section{References}

Alliance of Excellent Education. (2004). Tapping the potential: Retaining and developing high-quality teachers. Retrieved May 22, 2006, from http://www.all4ed.org/publications.

Archibald, J., Pidgeon, M., Janvier, S., Commodore, H., \& McCormick, R. (2002). Teacher recruitment, retention and training: Implications for First Nations education: A literature review. Ottawa, Canada: Minister's Working Group on Education, Indian and Northern Affairs, 1-30.

Ascher, M. (1991). Ethnomathematics: A multicultural view of mathematical ideas. Pacific Grove, CA: Brooks and Cole.

Avila de Lima, J. (2003). Trained for isolation: The impact of departmental cultures on student teachers' views and practices of collaboration. Journal of Education for Teaching, 29(3), 197-218.

Barnhardt, R. (2005). Creating a place for Indigenous Knowledge in education: The Alaska Native Knowledge Network. In G. Smith \& D. Gruenewald (Eds.), Placebased education in the global age: Local diversity (pp. 113-133). Hillsdale, NJ: Lawrence Erlbaum.

Bartell, C.A. (2005). Cultivating high quality teaching through induction and mentoring. Thousand Oaks, CA: Corwin Press.

Battiste, M. (2002). Indigenous knowledge and pedagogy in First Nations education: A literature review with recommendations. Prepared for the National Working Group on Education. Ottawa, ON., 1-69.

Battiste, M. (2008). The struggle and renaissance of Indigenous Knowledge in Eurocentric education. In M. Villegas, S.R. Neugebauer, \& K.R. Venegas (Eds.), Indigenous Knowledge and education (pp. 85-91). Cambridge, MA: Harvard Educational Review.

Battiste, M., Bell, L., Findlay, I.M., Findlay, L., \& Henderson, J.Y. (2005). Thinking place: Animating the Indigenous humanities in education. Australian Journal of Indigenous Education, 34, 11.

Brayboy, B.M.J. (2005). Toward a tribal critical race theory in education. The Urban Review, 37, 425-446.

Burnaby. (1996). Aboriginal language maintenance, development, and enhancement: A review of literature. In G. Cantoni (Ed.), Stabilizing Indigenous Languages. Flagstaff: Northern Arizona University.

Canadian Council on Learning. (2007). Redefining how success is measured in First Nations, Inuit and Métis Learning. Report on Learning in Canada. Ottawa, ON: Author.

Cajete, G. (1994). Look to the mountain: An ecology of indigenous education. Durango, CO: Kivaki Press. 
Cajete, G. (2008). Sites of strength in Indigenous research. In M. Villegas, S.R. Neugebauer, \& K.R. Venegas (Eds.), Indigenous Knowledge and education (pp. 204-207). Cambridge, MA: Harvard Educational Review.

Castellano, M. (1997). Updating Aboriginal traditions in knowledge. In G. J. S. Dei, B. Hall, \& D. Goldin Rosenbert (Eds.) Indigenous knowledge in global contexts. Toronto, Canada: University of Toronto Press.

Country Roads: Pathways to Better Education and Training for Rural and Remote Western Australia. (2000). ERIC Document Reproduction Service No. ED455978).

Creswell, J. W. (1998). Qualitative inquiry and research design: Choosing among five traditions. Thousand Oaks, CA: Sage.

Danielson, L. (2002). Developing and retaining quality classroom teachers through mentoring. Clearing House, 75(4), 183-185.

Darling-Hammond, L. (2003). Keeping good teachers: Why it maters, what leaders can do. Educational Leadership, 60(8), 6-13.

Dei, G.J.S., James, I.M., Karumanchery, L.K., James-Wilson, S., \& Zine, J. (2000). Removing the margins: The challenges and possibilities of inclusive schooling. Toronto, ON: Canadian Scholars Press.

Elijah. (2002). Literature Review: Language and Culture. Prepared for the Minister's National Working Group on Education.

Ermine, W. (1995). Aboriginal epistemology. In M. Battiste and J. Barman (Eds.), First Nations education in Canada: The circle unfolds. (pp. 101-111). Vancouver, BC: University of British Columbia Press.

Freire, P. (1985). The politics of education: Culture, power and liberation. South Hadley, MA: Bergin \& Garvey.

Giroux, H. (1992). Border crossing: Cultural workers and the politics of education. New York: Routledge.

Glaser, B. G., \& Strauss, A. (1967). The discovery of grounded theory: Strategies for qualitative research. Chicago: Aldine.

Goldsmith, C. (1993). Training the teachers of Aboriginal children. Paper presented as part of the Research Program of the Royal Commission on Aboriginal Peoples. CD ROM. Ottawa, ON: Communications Group.

Guarino, C.M., Santibanez, L., \& Daley, G.A. (2006). Teacher recruitment and retention: A review of the recent empirical literature. Review of Educational Research, 76(2), 173-208.

Hargreaves, A., \& Fink, D. (2003). Sustaining leadership. Phi Delta Kappan, 693

Hilden, H. M., \& Honkasalo, M. L. (2006). Finnish nurses' interpretations of patient autonomy in the context of end-of-life decision making. Nursing Ethics, 13(1), 4151. 
Hill, D.M. (2000). Indigenous knowledge as a tool for self-determination and liberation. Paper presented at The National Association of Native American Studies Section, Houston, TX, 21-26.

Hirsch, E. (2006). Recruiting and retaining teachers in Mobile, Alabama: Educators on what it will take to staff all classrooms with quality teachers. Chapel Hill, NC: Center for Teaching Quality.

Hobson, A.J., Malderez, A., Tracey, L., \& Kerr, K. (2005). Teachers' experiences of initial teacher preparation, induction and early professional development in England. Journal of Education for Teaching, 31(2), 133-135.

Hodson, J. (2004). Learning and healing: A wellness pedagogy for Aboriginal teacher education. Unpublished master's thesis, Brock University, St. Catharines, Ontario, Canada.

Ingersoll, R.M., \& Smith, T.M. (2003). The wrong solution to the teacher shortage. Educational Leadership, 60(8), 30-33.

Iseke-Barnes, J. M. (2002). Aboriginal and indigenous people's resistance, the internet, and education. Race, Ethnicity and Education, 5(2), 171-198.

Kawagley, J. (1995). A Yupik worldview: A Pathway to ecology and spirit. Prospect Heights, IL: Waveland Press.

Kompf, M., \& Hodson, J. (2000). Keeping the seventh fire: Developing an undergraduate degree program for Aboriginal adult educators. Canadian Journal of Native Education, 24(2), 185-202.

Lomawaima, K.T., \& McCarty, T.L. (2006). To remain an Indian: Lessons in democracy from a century of native American education. New York: Teachers College Press.

Luft, J. (2005). Enthusiasm is not enough: Beginning teachers in primarily Hispanic settings. School Science and Mathematics, 105(3), 116-126.

McConaghy, C. (2002). Rethinking Indigenous education: Culturalism, colonialism, and the politics of knowing. Flaxton, Australia: Post Pressed.

McNinch. (1994). The recruitment and retention of Aboriginal teachers in Saskatchewan schools. SSTA Research Center Report \#94-10. (ERIC Document Reproduction Service No. ED380412).

Moody, L., \& Cordua-von Specht, I. (2005). Stones: Social capital in Canadian Aboriginal communities. In A. Dale \& J. Onyx (Eds.), Social capital and sustainable community development: A dynamic balance (pp. 127-140). Vancouver, BC: UBC Press.

Morgan, N. (2002). First Nations' jurisdiction over education: A literature review. $A$ Report to the Minister's National Working Group in First Nations Education, 169.

Moyle, D. (2005). Quality educators produce quality outcomes: Some thoughts on what this means in the context of teaching Aboriginal and Torres Strait Islander students in Australia's public education system. Primary and Middle Years Educator, 3(2), 1115. 
Neegan, E. (2005). Excuse me? Who are the first peoples of Canada? A historical analysis of Aboriginal education in Canada then and now. International Journal of Inclusive Education, 9(1), 3-15.

Ontario Ministry of Education. (2007). Ontario First Nation, Métis, and Inuit Education Policy Framework. Toronto, ON: Aboriginal Education Office.

Orr, J., \& Friesen, D. W. (1999). I think that what's happening in Aboriginal education is that we're taking control: Aboriginal teachers' stories of self-determinism. Teachers and Teaching, 5(2), 219-241.

Portner, H. (2002). Being mentored. Thousand Oaks, CA: Corwin Press.

Report of the Minister's National Working Group. (2002). Our children: Keepers of the sacred knowledge. Ottawa, ON: Department of Indian Affairs and Northern Development Canada.

Rippon, J.H., \& Martin, M. (2006). What makes a good induction supporter? Teaching and Teacher Education, 22, 84-99.

Sawyer, D. (1991). Native learning styles: Shorthand for instructional adaptations? Canadian Journal of Native Education, 18, 99-105.

Schissel, B., \& Wotherspoon, T. (2003). The legacy of school for Aboriginal people. New York: Oxford University Press.

Smith, L.T. (1999). Decolonizing methodologies: Research and Indigenous peoples. London: Zed Books.

Smith, T.M., \& Ingersoll, R.M. (2004). What are the effects of induction and mentoring on beginning teacher turnover? American Educational Research Journal, 41, 681- 714 .

Strauss, A., \& Corbin, J. (1990). Basics of qualitative research: Grounded theory procedures and techniques. Newbury Park, CA: Sage.

Tedla, E. (1992). Indigenous African education as a means for understanding the fullness of life: Amara traditional education. Journal of Black Studies, 23, 7-26.

Tuhiwai Smith, L. (1999). Decolonizing methodologies: Research and Indigenous peoples. Dunedin, NZ: University of Otago Press.

Tushnet, N.C., Briggs, D., Elliot, J., Esch, C., Haviland, D., Humphrey, D.C., et al. (2002, April). Final report of the independent evaluation of the beginning teacher support and assessment program. California Department of Education and the California Commission on Teacher Credentialing.

Wilkins, E.A., \& Clift, R.T. (2007). Building a network of support for new teachers. Action in Teacher Education, 28(4), 25-35.

Williams, A. (2003). Informal learning in the workplace: Case study of new teachers. Educational Studies, 29(2/3), 207-219.

Womack, C.S. (1999). Red on red: Native American Literary Separatism. Minneapolis: University of Minnesota Press. 
Younger, M., Brindley, S., Pedder, D., \& Haggar, H. (2004). Starting points: Student teachers' reasons for becoming teachers and their preconceptions of what this will mean. European Journal of Teacher Education, 27(3), 245-264. 